\title{
Sulfonic Acid Supported on Magnetic Methylene-Based Organosilica as an Efficient and Recyclable Nanocatalyst for Biodiesel Production via Esterification
}

\author{
Masoumeh Shaker and Dawood Elhamifar* \\ Department of Chemistry, Yasouj University, Yasouj, Iran
}

OPEN ACCESS

Edited by:

Meisam Tabatabaei

MARA University of

Technology, Malaysia

Reviewed by:

Qiuyun Zhang,

Anshun University, China

Anping Wang,

Guizhou Normal University, China

*Correspondence:

Dawood Elhamifar

d.elhamifar@yu.ac.ir

Specialty section

This article was submitted to

Bioenergy and Biofuels,

a section of the journal

Frontiers in Energy Research

Received: 26 February 2020

Accepted: 14 April 2020

Published: 27 May 2020

Citation:

Shaker M and Elhamifar D (2020) Sulfonic Acid Supported on Magnetic Methylene-Based Organosilica as an Efficient and Recyclable Nanocatalyst for Biodiesel Production via Esterification. Front. Energy Res. 8:78.

doi: 10.3389/fenrg.2020.00078
In this paper, a novel sulfonic acid containing magnetic methylene-based organosilica with core-shell structure $\left(\mathrm{Fe}_{3} \mathrm{O}_{4} @ \mathrm{OS}-\mathrm{SO}_{3} \mathrm{H}\right)$ is synthesized, characterized and its catalytic application is investigated for biodiesel production via esterification of carboxylic acids with alcohols. The $\mathrm{Fe}_{3} \mathrm{O}_{4} @ \mathrm{OS}-\mathrm{SO}_{3} \mathrm{H}$ was synthesized via co-condensation of tetraethyl orthosilicate (TEOS) and 1,2-bis(triethoxysilyl)methane (BTEM) around magnetite nanoparticles. The $\mathrm{Fe}_{3} \mathrm{O}_{4} @ \mathrm{OS}-\mathrm{SO}_{3} \mathrm{H}$ nanocatalyst was characterized by using FT-IR, PXRD, TGA, VSM, TEM and SEM techniques. The catalytic study showed that the $\mathrm{Fe}_{3} \mathrm{O}_{4} @ O S$ - $\mathrm{SO}_{3} \mathrm{H}$ nanocomposite can be used as an effective, powerful, selective and recyclable catalyst for the esterification of carboxylic acids with alcohols at $70^{\circ} \mathrm{C}$ under solvent-free conditions. This nanocatalyst was recovered and reused several times without significant decrease in efficiency and stability.

Keywords: magnetic nanocatalyst, biodiesel production, esterification, recoverable catalyst, solvent-free conditions

\section{INTRODUCTION}

Recently, the use of magnetic nanoparticles has received increasing attention in various industrial and medical applications, such as magnetic resonance imaging (Qiao et al., 2009; Liu et al., 2014; Ni et al., 2017), magnetic recording (Dai et al., 2010), drug delivery (Häfeli et al., 2009; Zhang J. et al., 2013), cancer treatment through magnetic hyperthermia (Lartigue et al., 2011; Kandasamy et al., 2018; Mejías et al., 2018), catalytic industry (Pourjavadi et al., 2012; Wang et al., 2013; Kainz and Reiser, 2014; Iglesias et al., 2015; Ghorbani-Vaghei and Izadkhah, 2018), and spintronic, optoelectronic, and electronic devices (Gandhi et al., 2018; Obeid et al., 2019). In general, the performance and application of these nanoparticles are influenced by their proper design and synthesis. To date, various magnetic nanoparticles have been synthesized, including pure metal nanoparticles $(\mathrm{Fe}, \mathrm{Co}, \mathrm{Ni})$, metal oxides $\left(\mathrm{Fe}_{3} \mathrm{O}_{4}, \gamma-\mathrm{Fe}_{2} \mathrm{O}_{3}\right)$, ferrites $\left(\mathrm{MFe}_{2} \mathrm{O}_{4}, \mathrm{M}=\mathrm{Cu}, \mathrm{Ni}, \mathrm{Mn}\right.$, $\mathrm{Mg}$, Co, or Zn), and metal alloys (FePt, CoPt) (Meng et al., 2011; Seinberg et al., 2012; Aissou et al., 2013; Wang et al., 2015; Antonello et al., 2017). Among different magnetic materials, iron oxides are usually the best due to their lower toxicity and good magnetic properties compared with those of other particles. However, these MNPs are highly sensitive to oxidation and aggregation as well as chemically reactive because of their high surface area (Liu et al., 2008; Demirer et al., 2015; Wu et al., 2016; Kolhatkar et al., 2017). These problems limit their widespread applications. Creating a suitable organic or inorganic coating on the surface of magnetic NPs is an efficient way 
to overcome these problems. Biopolymers such as dextran, polysorbates, polyaniline, chitosan, and polyethylene glycol; organic surfactants; silica; carbon; and bioactive substances such as liposomes, peptides, and ligands/receptors are important coatings for the protection of magnetic nanoparticles (Colombo et al., 2012; Zhang et al., 2013; Esfahani et al., 2014; Bohara et al., 2016; Kudr et al., 2017; Kalhor and Zarnegar, 2019). Since silica is recognized as "generally safe" in the FDA grouping and because of its poor chemical permeability and high availability of silanol groups on its surface for any modification, it has received much attention among researchers (Chen et al., 2010; Li et al., 2012; Mondal et al., 2012; Maleki et al., 2017; Hajian and Ehsanikhah, 2018; Abaeezadeh et al., 2019; Mirbagheri and Elhamifar, 2019; Nikoorazm and Erfani, 2019; Ramazani et al., 2019; Vahidian et al., 2020). In particular, modification of the surface of magnetite nanoparticles with organosilica precursors, in addition to protecting the magnetic properties of these NPs, increases the surface hydrophobicity due to the presence of organic groups. In fact, this hydrophobicity increases the application of core-shell-structured organosilicacoated magnetite NPs in catalytic and adsorption processes. The modification of magnetic silicas with organic functional groups is achieved via the simultaneous co-condensation of mono- or bis(trialkoxysilyl)organic units and tetraalkoxysilanes (TMOS or TEOS) over magnetic $\mathrm{Fe}_{3} \mathrm{O}_{4}$ NPs (Li et al., 2012; Elhamifar et al., 2018; Mirbagheri and Elhamifar, 2019). Some of recently developed magnetic nanostructures with silica shells are $\mathrm{Fe}_{3} \mathrm{O}_{4} @ \mathrm{SiO}_{2} @ \mathrm{PMMA}$ (Chen et al., 2010), $\mathrm{Fe}_{3} \mathrm{O}_{4} @$ @mesoporous SBA-15 (Mondal et al., 2012), Fe $\mathrm{O}_{4} @ \mathrm{MCM}-41 @ \mathrm{Cu}-\mathrm{P} 2 \mathrm{C}$ (Nikoorazm and Erfani, 2019), $\mathrm{Fe}_{3} \mathrm{O}_{4} @ M C M-41-I m @ M n P o r$ (Hajian and Ehsanikhah, 2018), $\mathrm{CoFe}_{2} \mathrm{O}_{4} @ \mathrm{~B}_{2} \mathrm{O}_{3}-\mathrm{SiO}_{2}$ (Maleki et al., 2017), and $\mathrm{Fe}_{3} \mathrm{O}_{4} @ \mathrm{nSiO}_{2} @ \mathrm{PMO}$ (Li et al., 2012).

On the other hand, due to the environmental pollution caused by fossil fuels and the non-renewability of their sources, the need for new energy sources in today's world is increasingly felt. Biodiesels, monoalkyl esters of long-chain fatty acids, have attracted the attention of many researchers as one of the clean renewable fuels. Using biodiesel reduces carbon dioxide emission into the environment (Yang et al., 2008; Kondamudi et al., 2009; Haas et al., 2010; Hu et al., 2012). Biodiesel is produced from vegetable or animal oils. With the growing population and the limitation of water and soil resources for food supply, not only does the use of edible oils as fuel destroy food sources but also it is not economically viable. Therefore, the use of non-edible oils as feedstock for biodiesel fuel production is more attractive. Some of non-edible oils for biodiesel production are Putranjiva oil (Putranjiva roxburghii), neem oil (Azadirachta indica), Honge oil (Pongamia pinnata), and Jatropha curcas oil (Jatropha curcas L.) (Pan et al., 2018; Zhang et al., 2018a,b; Adeniyi et al., 2019).

The usual method for biodiesel production is the esterification of carboxylic acids and/or alcohols in the presence of homogeneous catalysts (Lien et al., 2010; Socha and Sello, 2010; Lam et al., 2019). However, this strategy suffers from problems such as catalyst and product separation and non-recoverability of the catalyst. Therefore, the recent methods have been developed based on the use of heterogeneous catalysts. Nevertheless, the use of heterogeneous catalysts in industrial applications also faces limitations such as mass transfer resistance and being time consuming. Nanocatalysts, due to their high surface area and high catalytic activity, can solve the above problems (Chen et al., 2007; Elhamifar et al., 2014; Dimian and Rothenberg, 2016; Laskar et al., 2018; Zhang et al., 2019). Especially, magnetic nanocatalysts are a good option in this regard because their easy magnetic separation avoids catalyst wastage and increases their reuse compared with filtration. Accordingly, a set of different magnetic nanocatalysts has been designed and used in biodiesel production (Hu et al., 2011; Chiang et al., 2015; Dos SantosDurndell et al., 2018; Xie et al., 2018; Gardy et al., 2019; Sarno and Iuliano, 2019; Touqeer et al., 2019; Xie and Huang, 2019). Some of recently developed nanocatalysts are $\mathrm{Fe}_{3} \mathrm{O}_{4} / \mathrm{Au} @ \mathrm{CA}-\mathrm{L}$ (Sarno and Iuliano, 2019), $\mathrm{Fe}_{3} \mathrm{O}_{4} / \mathrm{MCM}-41 / \mathrm{ECH} / \mathrm{Na}_{2} \mathrm{SiO}_{3}$ (Xie et al., 2018), TBD-Fe $\mathrm{O}_{4} @$ silica (Chiang et al., 2015), KF/CaO- $\mathrm{Fe}_{3} \mathrm{O}_{4}$ (Hu et al., 2011), $\mathrm{Fe}_{3} \mathrm{O}_{4} @ \mathrm{MIL}-100$ (Fe) (Xie and Huang, 2019), $\mathrm{Fe}_{3} \mathrm{O}_{4}$-PDA-Lipase (Touqeer et al., 2019), $\mathrm{SO}_{4} / \mathrm{Mg}-\mathrm{Al}-\mathrm{Fe}_{3} \mathrm{O}_{4}$ (Gardy et al., 2019), and Mag/Si (Dos Santos-Durndell et al., 2018).

In continuation of the abovementioned studies, in this study, due to the importance of biodiesel fuels and magnetic organosilica NPs in the catalyst world, we have prepared and developed a novel sulfonic acid containing magnetic organosilica as an effective, powerful, recyclable, and reusable nanocatalyst in the esterification process to produce biodiesel products.

\section{EXPERIMENTAL SECTION \\ Preparation of $\mathrm{Fe}_{3} \mathrm{O}_{4} @ \mathrm{OS}-\mathrm{SH}$}

For this purpose, $\mathrm{Fe}_{3} \mathrm{O}_{4}$ and $\mathrm{Fe}_{3} \mathrm{O}_{4} @ \mathrm{SiO}_{2}$ MNPs were first synthesized according to methods presented by us in previous research studies (Elhamifar et al., 2018; Neysi et al., 2019). Then, $\mathrm{Fe}_{3} \mathrm{O}_{4} @ O S$ MNPs were prepared via co-condensation of tetraethyl orthosilicate (TEOS) and 1,2bis(triethoxysilyl)methane (BTEM) around $\mathrm{Fe}_{3} \mathrm{O}_{4} @ \mathrm{SiO}_{2}$ NPs. For this, $0.5 \mathrm{~g}$ of $\mathrm{Fe}_{3} \mathrm{O}_{4} @ \mathrm{SiO}_{2}$ was completely dispersed in a mixture of $\mathrm{H}_{2} \mathrm{O}(12 \mathrm{~mL})$ and $\mathrm{EtOH}(50 \mathrm{~mL})$ for $30 \mathrm{~min}$. After that, ammonia $(2 \mathrm{~mL}, 25 \%)$ was added in the reaction vessel, and the resulting mixture was stirred at RT for $10 \mathrm{~min}$. Then, tetraethyl orthosilicate (TEOS, $1 \mathrm{mmol}$ ) and 1,2bis(triethoxysilyl)methane (BTEM, $1 \mathrm{mmol}$ ) were simultaneously added in the reaction vessel, and this combination was stirred at RT for $16 \mathrm{~h}$. Next, the resulting product was collected using a magnetic field and washed several times with $\mathrm{H}_{2} \mathrm{O}$ and EtOH. The obtained material was dried at $70^{\circ} \mathrm{C}$ and called $\mathrm{Fe}_{3} \mathrm{O}_{4} @ \mathrm{OS}$. For the preparation of $\mathrm{Fe}_{3} \mathrm{O}_{4} @ \mathrm{OS}-\mathrm{SH}, 0.5 \mathrm{~g}$ of $\mathrm{Fe}_{3} \mathrm{O}_{4} @ \mathrm{OS}$ was dispersed in dry toluene $(25 \mathrm{~mL})$ for $30 \mathrm{~min}$. Then, (3-mercaptopropyl)trimethoxysilane $(1 \mathrm{mmol})$ was added to the reaction flask, and the mixture was refluxed. After $24 \mathrm{~h}$, the resulting material was separated using a magnet and washed with $\mathrm{EtOH}$ and $\mathrm{H}_{2} \mathrm{O}$. The final product was dried at $70^{\circ} \mathrm{C}$ for $6 \mathrm{~h}$ and called $\mathrm{Fe}_{3} \mathrm{O}_{4} @ O S-\mathrm{SH}$ (Tai et al., 2017).

\section{Preparation of the $\mathrm{Fe}_{3} \mathrm{O}_{4} @ \mathrm{OS}-\mathrm{SO}_{3} \mathrm{H}$ Nanocatalyst}

For this, $0.5 \mathrm{~g}$ of $\mathrm{Fe}_{3} \mathrm{O}_{4} @ \mathrm{OS}$-SH was completely dispersed in $\mathrm{MeOH}(20 \mathrm{~mL})$ under ultrasonic conditions for $20 \mathrm{~min}$. Then, 
$\mathrm{H}_{2} \mathrm{O}_{2}(35 \%, 5 \mathrm{~mL})$ was added to the reaction vessel, for oxidation of $\mathrm{SH}$ groups to $\mathrm{SO}_{3} \mathrm{H}$ counterparts, and the resulting mixture was stirred at RT for $24 \mathrm{~h}$. After this process, the resulting product was collected by using a magnetic field and washed three times with $\mathrm{H}_{2} \mathrm{O}$ and EtOH. To ensure complete protonation, the obtained material was acidified in a $\mathrm{H}_{2} \mathrm{SO}_{4}$ solution $(0.1 \mathrm{M}$, $25 \mathrm{~mL}$ ) for $5 \mathrm{~h}$. Then, the solid product was collected using an external magnet, washed completely with deionized water, dried at $70^{\circ} \mathrm{C}$ for $12 \mathrm{~h}$, and denoted as $\mathrm{Fe}_{3} \mathrm{O}_{4} @ \mathrm{OS}-\mathrm{SO}_{3} \mathrm{H}$.

\section{Procedure for the Determination of the Acidity of $\mathrm{Fe}_{3} \mathrm{O}_{4} @ \mathrm{OS}-\mathrm{SO}_{3} \mathrm{H}$}

For this, $50 \mathrm{mg}$ of $\mathrm{Fe}_{3} \mathrm{O}_{4} @ \mathrm{OS}-\mathrm{SO}_{3} \mathrm{H}$ was dispersed in an aqueous solution of sodium chloride $(1 \mathrm{M}, 25 \mathrm{~mL})$ for $20 \mathrm{~min}$, and it was then stirred at room temperature for $72 \mathrm{~h}$. After this, an inverse titration was carried out on the resulting mixture by using $\mathrm{NaOH}(0.05 \mathrm{M})$, and the loading of sulfonic acid groups on the $\mathrm{Fe}_{3} \mathrm{O}_{4} @ \mathrm{OS}-\mathrm{SO}_{3} \mathrm{H}$ surface was calculated $\left(2.1 \mathrm{mmol} \mathrm{g}{ }^{-1}\right)$.

\section{General Procedure for the Esterification of Carboxylic Acids in the Presence of the $\mathrm{Fe}_{3} \mathrm{O}_{4}-\mathrm{OS}-\mathrm{SO}_{3} \mathrm{H}$ Nanocatalyst}

For this purpose, carboxylic acid (5 $\mathrm{mmol})$, alcohol $(2 \mathrm{mmol})$, and $\mathrm{Fe}_{3} \mathrm{O}_{4} @ \mathrm{OS}-\mathrm{SO}_{3} \mathrm{H}$ nanocatalyst $(0.03 \mathrm{~g})$ were added into a reaction vessel, and this mixture was stirred vigorously at $70^{\circ} \mathrm{C}$. The progress of the reaction was monitored by TLC and GC. After finishing the process, ethyl acetate $(5 \mathrm{~mL})$ was added, and the catalyst was collected using an external magnet. Then, the residue was decanted with a mixture of ethyl acetate and $\mathrm{H}_{2} \mathrm{O}$ to remove unreacted carboxylic acid. The organic phase was separated and dried over anhydrous $\mathrm{Na}_{2} \mathrm{SO}_{4}$. A pure ester product resulted after evaporation of the solvent.

\section{Procedure for the Hot Filtration Test}

This test was also performed on the esterification of acetic acid by 1-octanol under optimized conditions. For this, after about $50 \%$ of the reaction had been completed, it was stopped and the catalyst was separated using an external magnetic field. The catalyst-free residue was allowed to continue to undergo reaction under optimum conditions. After about $20 \mathrm{~h}$, no noticeable conversion was observed, confirming no leaching of active sulfonic acid moieties during reaction conditions.

\section{RESULTS AND DISCUSSION}

Firstly, $\mathrm{Fe}_{3} \mathrm{O}_{4}$ and $\mathrm{Fe}_{3} \mathrm{O}_{4} @ \mathrm{SiO}_{2}$ NPs were first prepared according to our reported methods (Elhamifar et al., 2018; Neysi et al., 2019). Then, $\mathrm{Fe}_{3} \mathrm{O}_{4} @ \mathrm{OS}$ was synthesized via co-condensation of TEOS and BTEM around $\mathrm{Fe}_{3} \mathrm{O}_{4} @ \mathrm{SiO}_{2}$ NPs. Next, the surface of $\mathrm{Fe}_{3} \mathrm{O}_{4} @ \mathrm{OS}$ NPs was chemically modified with (3-mercaptopropyl)trimethoxysilane groups to give $\mathrm{Fe}_{3} \mathrm{O}_{4} @ \mathrm{SiO}_{2}-\mathrm{SH}$ nanomaterial. Finally, the $\mathrm{SH}$ moieties of the latter material were oxidized in the presence of $\mathrm{H}_{2} \mathrm{O}_{2}$ to deliver the desired $\mathrm{Fe}_{3} \mathrm{O}_{4} @ \mathrm{OS}-\mathrm{SO}_{3} \mathrm{H}$ nanocatalyst (Scheme 1). $\mathrm{Fe}_{3} \mathrm{O}_{4} @ \mathrm{OS}-\mathrm{SO}_{3} \mathrm{H}$ was characterized using various techniques, namely, FT-IR, PXRD, VSM, TEM, SEM, and TGA.

Firstly, the FT-IR spectroscopy technique was used to identify the functional groups of the prepared nanomaterials at each step (Figure 1). The observed peak at $576 \mathrm{~cm}^{-1}$ for all samples is related to the stretching vibrations of the $\mathrm{Fe}-\mathrm{O}$ bonds. For $\mathrm{Fe}_{3} \mathrm{O}_{4} @ \mathrm{SiO}_{2}, \mathrm{Fe}_{3} \mathrm{O}_{4} @ \mathrm{OS}$, and $\mathrm{Fe}_{3} \mathrm{O}_{4} @ \mathrm{OS}-\mathrm{SO}_{3} \mathrm{H}$, the
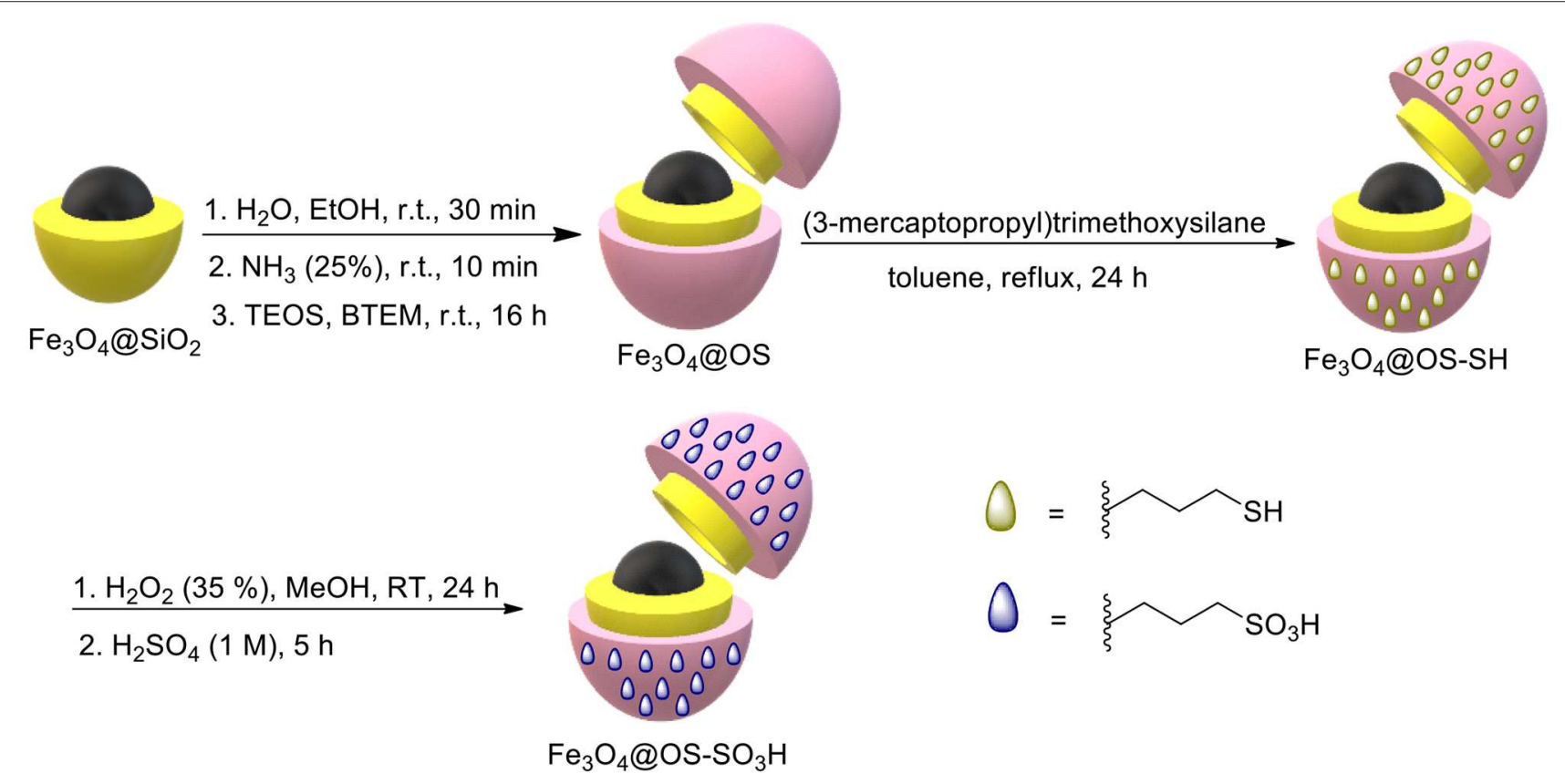

SCHEME 1 | Preparation of the $\mathrm{Fe}_{3} \mathrm{O}_{4} @ \mathrm{OS}-\mathrm{SO}_{3} \mathrm{H}$ nanocatalyst. 


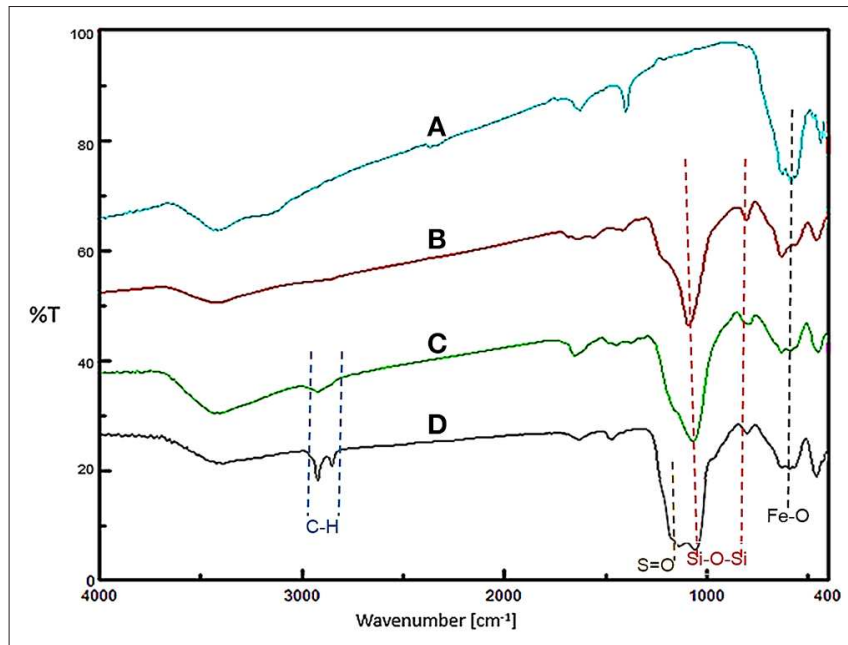

FIGURE 1 | FT-IR spectra of (A) $\mathrm{Fe}_{3} \mathrm{O}_{4}$, (B) $\mathrm{Fe}_{3} \mathrm{O}_{4} @ \mathrm{SiO}_{2}$, (C) $\mathrm{Fe}_{3} \mathrm{O}_{4} @ \mathrm{OS}$, and (D) $\mathrm{Fe}_{3} \mathrm{O}_{4} @ \mathrm{OS}-\mathrm{SO}_{3} \mathrm{H}$ nanomaterials.

asymmetric and symmetric stretching vibrations of the $\mathrm{Si}-\mathrm{O}-\mathrm{Si}$ bonds appeared at 930 and $1,079 \mathrm{~cm}^{-1}$. The peaks at 2,800-2,930 $\mathrm{cm}^{-1}$ can be attributed to the stretching vibration of aliphatic $\mathrm{C}-\mathrm{H}$ bonds of propyl moieties (Figures 1C,D). Importantly, for the $\mathrm{Fe}_{3} \mathrm{O}_{4} @ \mathrm{OS}-\mathrm{SO}_{3} \mathrm{H}$ nanomaterial, the peak observed around $1,105 \mathrm{~cm}^{-1}$ is assigned to the $\mathrm{S}=\mathrm{O}$ stretching vibration of the sulfonic acid groups (Figure 1D), indicating successful oxidation of $\mathrm{SH}$ to $\mathrm{SO}_{3} \mathrm{H}$ moieties.

In the following, the surface acidity of the $\mathrm{Fe}_{3} \mathrm{O}_{4} @ \mathrm{OS}$ $\mathrm{SO}_{3} \mathrm{H}$ nanocatalyst was evaluated by FT-IR spectroscopy using pyridine as a probe molecule. Figure $2 \mathrm{~A}$ shows the FT-IR spectrum of the nanocatalyst before pyridine adsorption, where no special bands corresponding to pyridine are observed in the region $1,400-1,700 \mathrm{~cm}^{-1}$. In contrast, Figure $2 \mathbf{B}$ shows that after pyridine adsorption, three peaks clearly appear in regions $1,487,1,542$, and $1,640 \mathrm{~cm}^{-1}$. These emerging bands are due to the interaction of pyridine with Brønsted acid sites to form pyridinium ions, confirming well the immobilization and high stability of sulfonic acid groups on the $\mathrm{Fe}_{3} \mathrm{O}_{4} @ \mathrm{OS}$ support (Hamoudi and Kaliaguine, 2003; Adam et al., 2012; Upare et al., 2013).

The powder X-ray diffraction (PXRD) analysis of $\mathrm{Fe}_{3} \mathrm{O}_{4}$, $\mathrm{Fe}_{3} \mathrm{O}_{4} @ \mathrm{OS}$, and $\mathrm{Fe}_{3} \mathrm{O}_{4} @ \mathrm{OS}-\mathrm{SO}_{3} \mathrm{H}$ nanomaterials showed six sharp peaks at $2 \theta: 30.15,35.73,43.38,54.09,57.37$, and 62.89 degrees, corresponding to Miller indices of 220, 311, 400, 422, 511, and 440, respectively (Figure 3) (Zhang et al., 2014; Liu et al., 2015). The results of this analysis prove that the $\mathrm{Fe}_{3} \mathrm{O}_{4}$ crystalline structure is preserved during the modification processes (Figure 3). Also, the broad peaks appearing at $2 \theta=20$ 25 degrees in Figures 3B,C are related to organosilica, confirming the formation of an organosilica shell around the $\mathrm{Fe}_{3} \mathrm{O}_{4}$ core. It also should be noted that the observation of later peaks at $2 \theta=$ 20-25 degrees in Figure 3C confirms the chemical stability of the organosilica shell during the surface modification process by the sulfonic acid group (Lee et al., 2008; Wang et al., 2012).

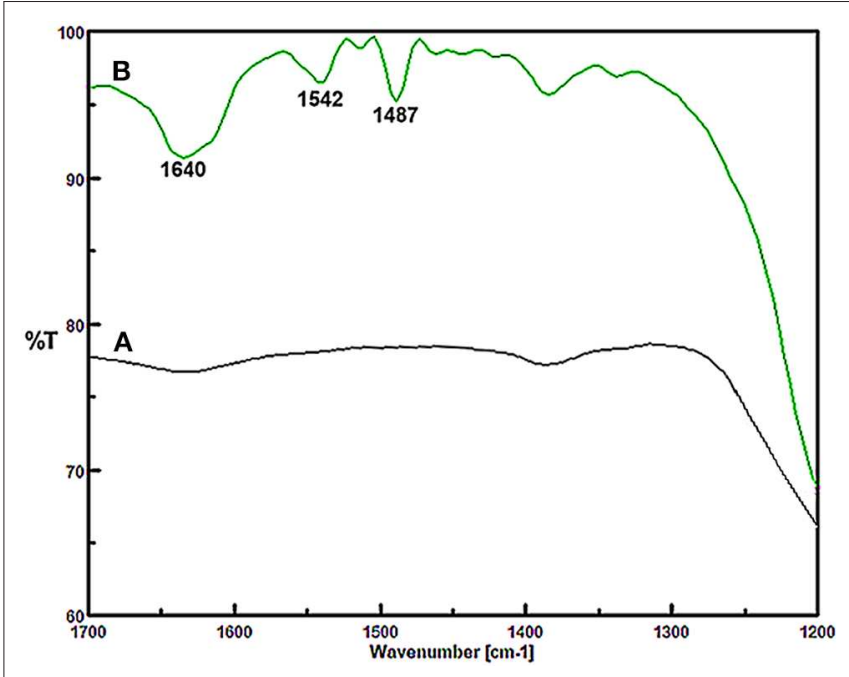

FIGURE 2 | FT-IR spectra of (A) $\mathrm{Fe}_{3} \mathrm{O}_{4} @ \mathrm{OS}-\mathrm{SO}_{3} \mathrm{H}$ nanocatalyst and (B) $\mathrm{Fe}_{3} \mathrm{O}_{4} @ \mathrm{OS}-\mathrm{SO}_{3} \mathrm{H}$ nanocatalyst after pyridine adsorption.

The magnetic properties of $\mathrm{Fe}_{3} \mathrm{O}_{4}, \mathrm{Fe}_{3} \mathrm{O}_{4} @ \mathrm{SiO}_{2}, \mathrm{Fe}_{3} \mathrm{O}_{4} @ \mathrm{OS}$, and $\mathrm{Fe}_{3} \mathrm{O}_{4} @ \mathrm{OS}-\mathrm{SO}_{3} \mathrm{H}$ nanomaterials were investigated by vibrating sample magnetometer (VSM) analysis. The results of this analysis showed that all samples have a superparamagnetic behavior with no hysteresis, remanence, and coercivity. The magnetic saturation of $\mathrm{Fe}_{3} \mathrm{O}_{4}, \mathrm{Fe}_{3} \mathrm{O}_{4} @ \mathrm{SiO}_{2}, \mathrm{Fe}_{3} \mathrm{O}_{4} @ \mathrm{OS}$, and $\mathrm{Fe}_{3} \mathrm{O}_{4} @ \mathrm{OS}-\mathrm{SO}_{3} \mathrm{H}$ nanomaterials were 75, 55, 47, and $38 \mathrm{emu} / \mathrm{g}$, respectively. The decrease in saturation magnetization, after each step, confirms successful chemical immobilization of silica precursors and sulfonic acid moieties on the surface of the $\mathrm{Fe}_{3} \mathrm{O}_{4}$ NPs (Figure 4). Also, this confirms the high magnetic properties of all prepared materials, which are very important for their easy separation in the chemical processes.

The morphology of the particles at different steps of nanocatalyst preparation was investigated by using SEM (Figure 5). This showed a spherical morphology with a uniform size of the particles at different stages. Also, this confirmed that the size of the NPs increased at each step compared with that at the previous step. Especially, the SEM of $\mathrm{Fe}_{3} \mathrm{O}_{4} @ \mathrm{OS}$ $\mathrm{SO}_{3} \mathrm{H}$ clearly showed the presence of spherical particles with an average size of $70 \mathrm{~nm}$ (Figure 5D). These types of particles are very good candidates in the catalytic, chromatography, and adsorption processes.

The transmission electron microscopy (TEM) image also showed that the designed nanocatalyst has a core-shell structure with a black core (magnetite particles) and a gray shell (organosilica layer) (Figure 6).

Thermogravimetric analysis (TGA) was used for the investigation of the thermal stability of $\mathrm{Fe}_{3} \mathrm{O}_{4} @ \mathrm{OS}$ and $\mathrm{Fe}_{3} \mathrm{O}_{4} @ \mathrm{OS}-\mathrm{SO}_{3} \mathrm{H}$ nanocomposites (Figure 7). As shown, the TGA of both $\mathrm{Fe}_{3} \mathrm{O}_{4} @ \mathrm{OS}$ and $\mathrm{Fe}_{3} \mathrm{O}_{4} @ \mathrm{OS}-\mathrm{SO}_{3} \mathrm{H}$ samples has approximately the same pattern. This shows three weight losses. The first weight loss (about $3 \%$ ) below $150^{\circ} \mathrm{C}$ corresponds to the removal of adsorbed water and alcoholic solvents remaining from the preparation process. The second weight 


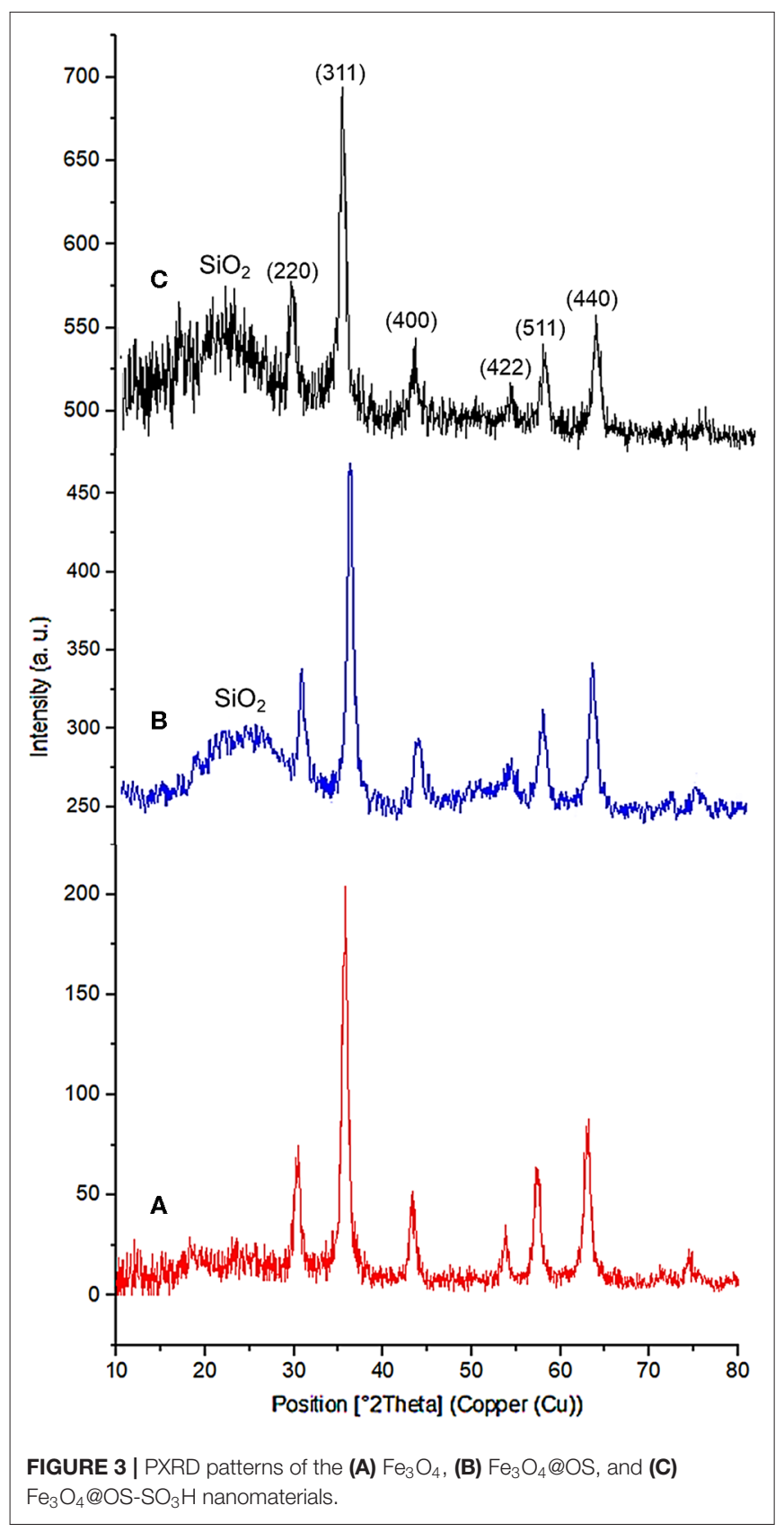

loss (about $8 \%$ ) between 180 and $250^{\circ} \mathrm{C}$ is due to the removal of supported propanethiol/propanesulfonic acid moieties. The main weight loss (about 22\%) cleared between 251 and $600^{\circ} \mathrm{C}$ is due to the removal of incorporated methylene groups in the shell framework. These results prove the high thermal stability of the $\mathrm{Fe}_{3} \mathrm{O}_{4} @ \mathrm{OS}$ and $\mathrm{Fe}_{3} \mathrm{O}_{4} @ \mathrm{OS}-\mathrm{SO}_{3} \mathrm{H}$ nanocomposites and confirm well immobilization/incorporation of propanethiol/propanesulfonic acid and methylene groups onto/into the material framework.

After successful characterization of $\mathrm{Fe}_{3} \mathrm{O}_{4} @ \mathrm{OS}-\mathrm{SO}_{3} \mathrm{H}$, its catalytic activity was investigated in esterification of carboxylic acids to produce biodiesel products. In order to achieve the

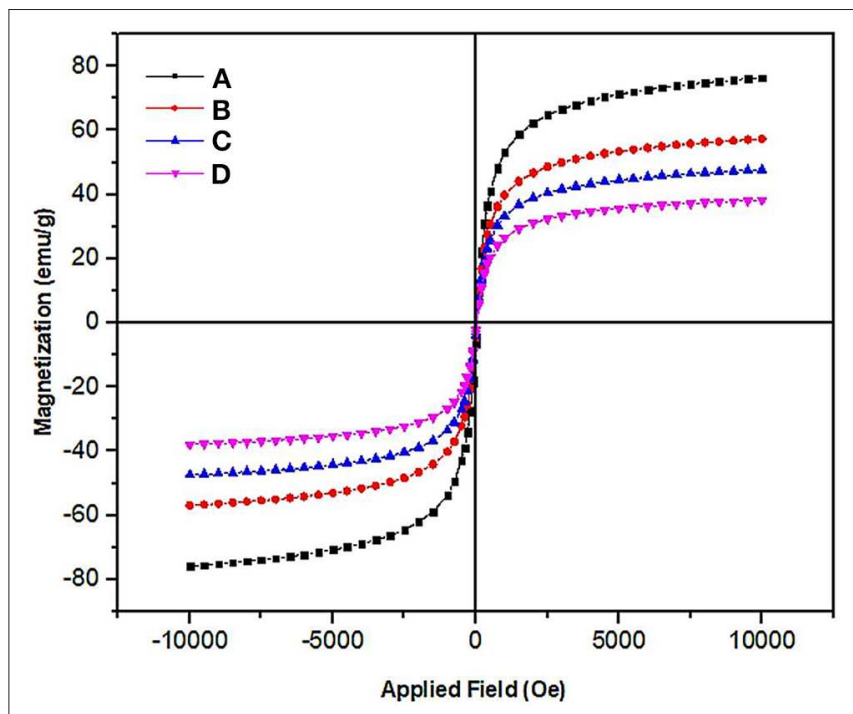

FIGURE 4 | VSM diagram of the (A) $\mathrm{Fe}_{3} \mathrm{O}_{4}$, (B) $\mathrm{Fe}_{3} \mathrm{O}_{4} @ \mathrm{SiO}_{2}$, (C) $\mathrm{Fe}_{3} \mathrm{O}_{4} @ \mathrm{OS}$, and (D) $\mathrm{Fe}_{3} \mathrm{O}_{4} @ \mathrm{OS}-\mathrm{SO}_{3} \mathrm{H}$ nanomaterials.

optimum conditions, the condensation between acetic acid and 1 -octanol was selected as the model reaction. The effects of temperature, catalyst loading, and catalyst type were investigated under solvent-free conditions (Table 1). The obtained results proved that the catalyst loading is very effective in the progress of the reaction and the best result was delivered in the presence of $0.03 \mathrm{~g}$ of the designed catalyst (Table 1 , entries $1-4$ ). The reaction was also affected by temperature, and the best conversion was obtained at $70^{\circ} \mathrm{C}$ (Table 1, entries 4-6). Figure 8A illustrates the influence of temperature on the progress of this process. In the following, to show the exact role of supported sulfonic acids in the catalytic process, the activity of $\mathrm{Fe}_{3} \mathrm{O}_{4} @ \mathrm{OS}-\mathrm{SH}$ and $\mathrm{Fe}_{3} \mathrm{O}_{4} @ \mathrm{OS}$ was studied and the result was compared with that of $\mathrm{Fe}_{3} \mathrm{O}_{4} @ \mathrm{OS}-\mathrm{SO}_{3} \mathrm{H}$ (Table 1, entry 4 vs. entries 7 and 8). Interestingly, both sulfonic acid-free nanomaterials delivered no ester product under the same conditions as $\mathrm{Fe}_{3} \mathrm{O}_{4} @ \mathrm{OS}$ $\mathrm{SO}_{3} \mathrm{H}$, confirming that the esterification process is completely catalyzed by supported $-\mathrm{SO}_{3} \mathrm{H}$ moieties. Next, the effect of the molar ratio of 1 -octanol to acetic acid was investigated. The results of this study showed that the yield of the desired ester is improved from 35 to $94 \%$ as the 1-octanol:acetic acid molar ratio changed from $0.5: 5$ to $2: 5$. It is also important to note that when the 1-octanol:acetic acid molar ratio was increased to 3:5, no significant change in the reaction yield was observed (Table 1, entry 4 vs. entries 9-11, Figure 8B). The effect of time on the progress of the esterification process proved that the conversion of starting materials increases steadily with increasing reaction time (Table 1, entry 4 vs. entries 12-15, Figure 8C). Accordingly, the use of $0.03 \mathrm{~g}$ of $\mathrm{Fe}_{3} \mathrm{O}_{4} @ \mathrm{OS}-\mathrm{SO}_{3} \mathrm{H}, 70^{\circ} \mathrm{C}$, and solvent-free conditions were chosen as optimum conditions.

After optimization of the reaction conditions, the catalytic activity of $\mathrm{Fe}_{3} \mathrm{O}_{4} @ \mathrm{OS}-\mathrm{SO}_{3} \mathrm{H}$ was investigated in the esterification of different carboxylic acids and alcohols (Table 2). The synthesis of ester products with high yields in this process proved that 

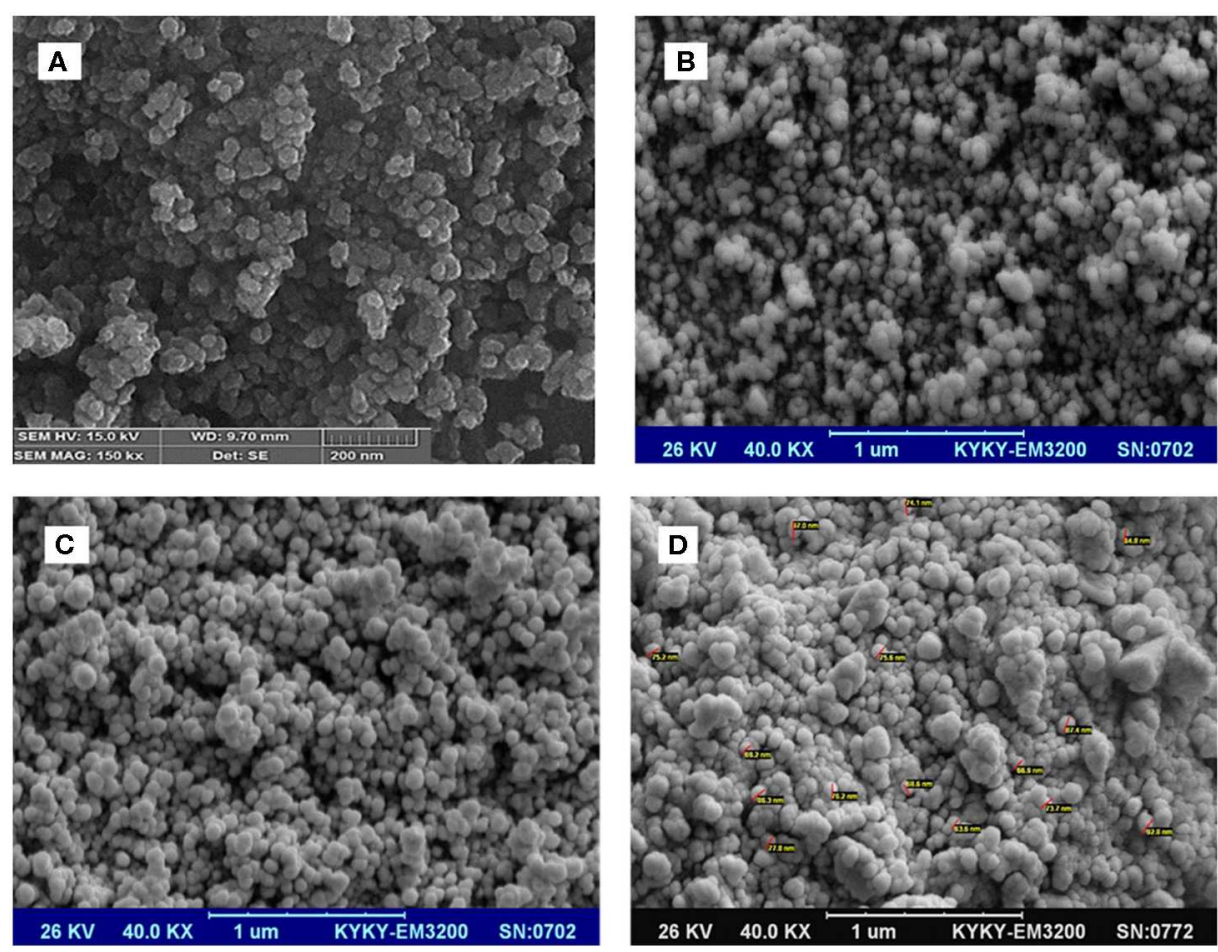

FIGURE 5 | SEM images of the (A) $\mathrm{Fe}_{3} \mathrm{O}_{4}$, (B) $\mathrm{Fe}_{3} \mathrm{O}_{4} @ \mathrm{SiO}_{2}$, (C) $\mathrm{Fe}_{3} \mathrm{O}_{4} @ O S$, and (D) $\mathrm{Fe}_{3} \mathrm{O}_{4} @ O$ S-SO $\mathrm{S}_{3} \mathrm{H}$ nanomaterials.

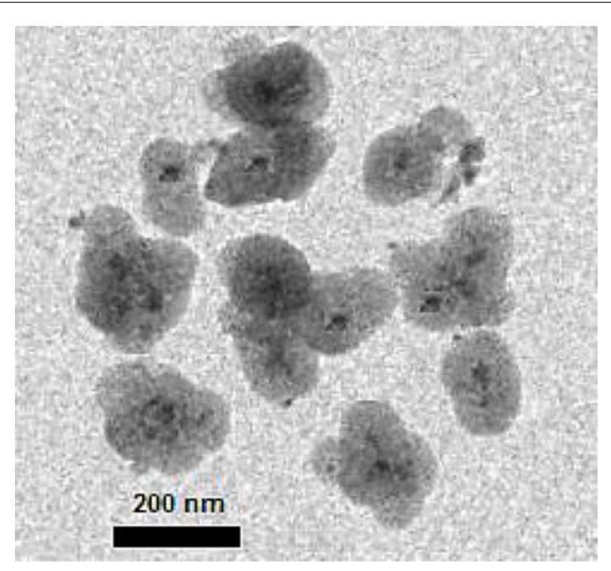

FIGURE 6 | The TEM image of the $\mathrm{Fe}_{3} \mathrm{O}_{4} @ \mathrm{OS}-\mathrm{SO}_{3} \mathrm{H}$ nanocatalyst.

$\mathrm{Fe}_{3} \mathrm{O}_{4} @ \mathrm{OS}-\mathrm{SO}_{3} \mathrm{H}$ is a powerful and efficient nanocatalyst for the preparation of a set of different esters applicable as biodiesel.

One of important properties of nanocatalysts is the recyclability and reusability of these materials without a significant change in their activity and structure. Therefore, next, the recyclability and reusability of $\mathrm{Fe}_{3} \mathrm{O}_{4} @ \mathrm{OS}-\mathrm{SO}_{3} \mathrm{H}$ were studied in the condensation of acetic acid and 1-octanol as a model reaction. The results showed that the $\mathrm{Fe}_{3} \mathrm{O}_{4} @ \mathrm{OS}-\mathrm{SO}_{3} \mathrm{H}$ nanocatalyst can be recycled and reused several times without a significant decrease in efficiency (Figure 9).

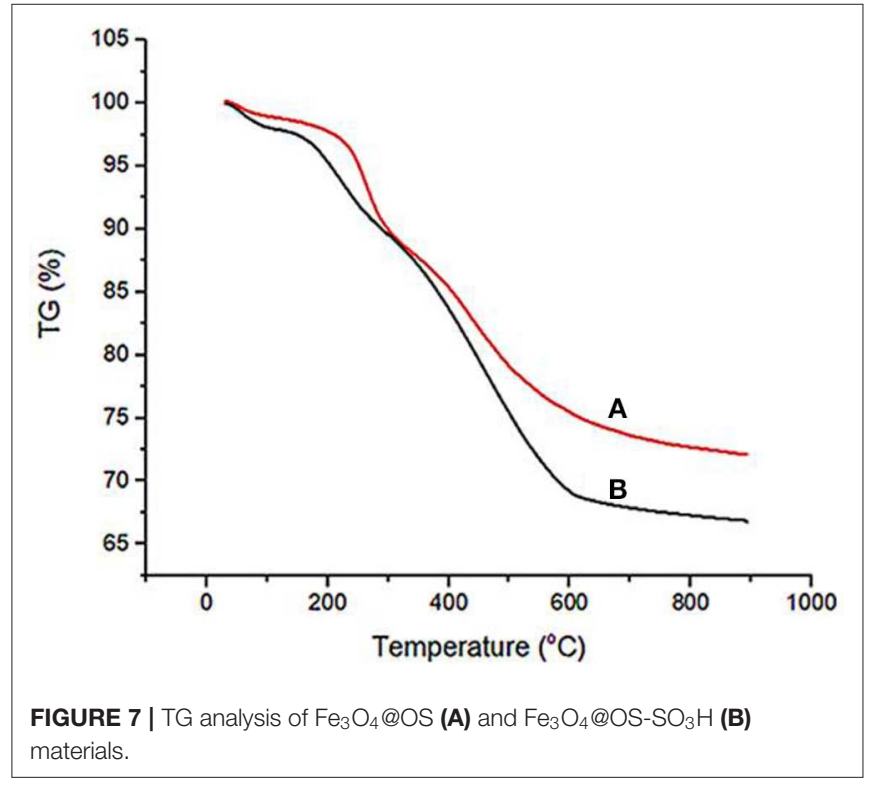

The IR and PXRD analyses of the recycled nanocatalyst were next performed to study its chemical and structural stability under the applied conditions.

As shown in Figure 10, the FT-IR spectrum of the recovered nanocatalyst is approximately the same as the FT-IR spectrum of the fresh nanocatalyst, confirming the high chemical stability of the $\mathrm{Fe}_{3} \mathrm{O}_{4} @ \mathrm{OS}-\mathrm{SO}_{3} \mathrm{H}$ nanocatalyst under the applied conditions. 

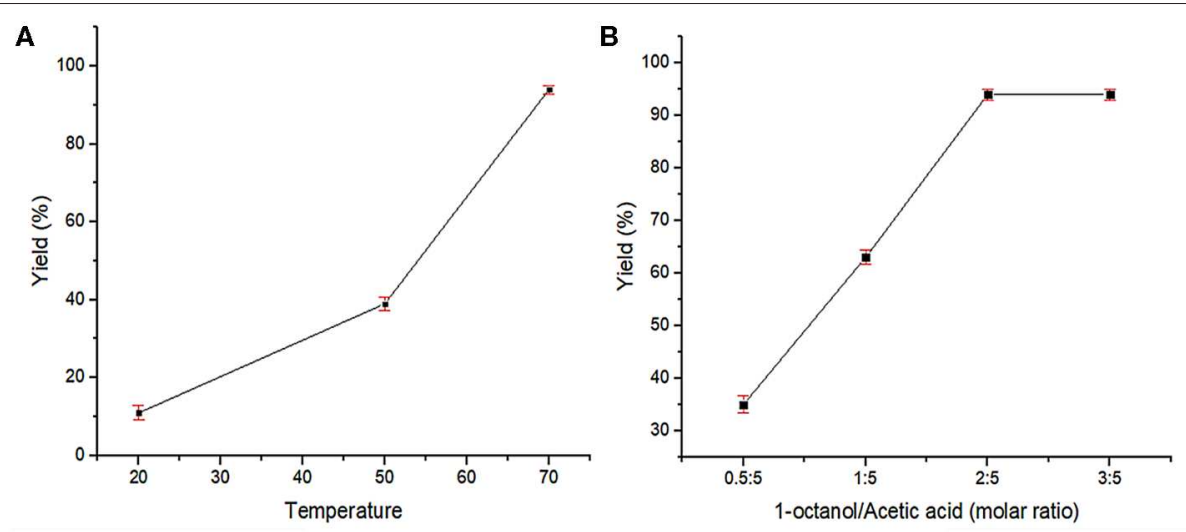

C

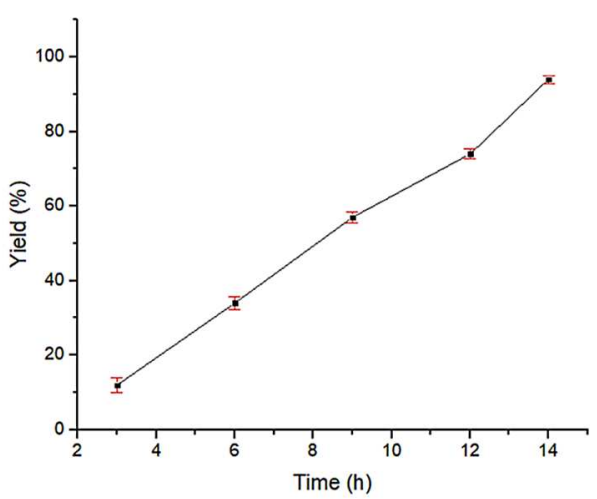

FIGURE 8 | Effects of reaction parameters in the esterification of acetic acid by 1-octanol: (A) reaction temperature, (B) molar ratio of 1-octanol to acetic acid, and (C) reaction time.

TABLE 1 | Effects of catalyst loading, temperature, and catalyst type in the esterification of acetic acid by 1-octanol.

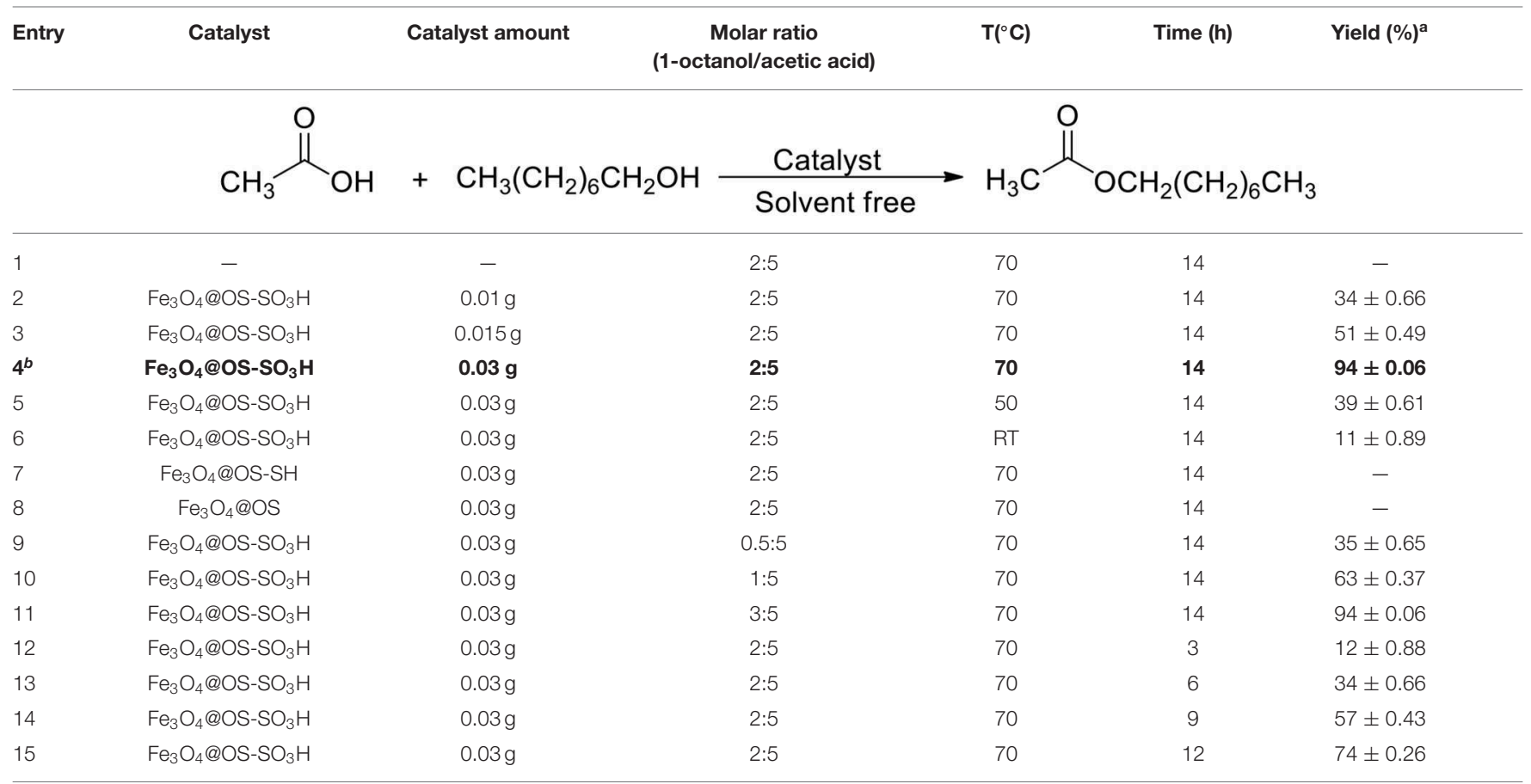

${ }^{a}$ Isolated yields. ${ }^{b}$ Bold values indicate the optimum condition. 
TABLE 2 | The esterification of carboxylic acids with alcohols in the presence of the $\mathrm{Fe}_{3} \mathrm{O}_{4} @ \mathrm{OS}-\mathrm{SO}_{3} \mathrm{H}$ nanocatalyst ${ }^{\mathrm{a}}$.

\begin{tabular}{|c|c|c|c|c|}
\hline Entry & $\mathbf{R}$ & R'OH & Time (h) & Yield $(\%)^{\mathrm{b}}$ \\
\hline & $\mathrm{R}^{\prime} \mathrm{OH}$ & $\mathrm{Fe}_{3} \mathrm{O}_{4} @ \mathrm{OS}-\mathrm{SO}_{3} \mathrm{H}$ & & \\
\hline & 1 & Solvent free, $70^{\circ} \mathrm{C}$ & & \\
\hline 1 & $\mathrm{CH}_{3}$ & $\mathrm{CH}_{3}\left(\mathrm{CH}_{2}\right)_{16} \mathrm{CH}_{2} \mathrm{OH}$ & 17 & $91 \pm 0.09$ \\
\hline 2 & $\mathrm{PhCH}_{2} \mathrm{CH}_{2}$ & $\mathrm{CH}_{3}\left(\mathrm{CH}_{2}\right)_{16} \mathrm{CH}_{2} \mathrm{OH}$ & 21 & $90 \pm 0.1$ \\
\hline 3 & $\mathrm{Ph}$ & $\mathrm{CH}_{3}\left(\mathrm{CH}_{2}\right)_{16} \mathrm{CH}_{2} \mathrm{OH}$ & 24 & $88 \pm 0.12$ \\
\hline 4 & $\mathrm{CH}_{3}\left(\mathrm{CH}_{2}\right)_{7} \mathrm{CH}=\mathrm{CH}\left(\mathrm{CH}_{2}\right)_{7}$ & $\mathrm{CH}_{3}\left(\mathrm{CH}_{2}\right)_{16} \mathrm{CH}_{2} \mathrm{OH}$ & 22 & $90 \pm 0.1$ \\
\hline 5 & $\mathrm{CH}_{3}$ & $\mathrm{CH}_{3}\left(\mathrm{CH}_{2}\right)_{6} \mathrm{CH}_{2} \mathrm{OH}$ & 14 & $94 \pm 0.06$ \\
\hline 6 & $\mathrm{CH}_{3}\left(\mathrm{CH}_{2}\right)_{7} \mathrm{CH}=\mathrm{CH}\left(\mathrm{CH}_{2}\right)_{7}$ & $\mathrm{CH}_{3}\left(\mathrm{CH}_{2}\right)_{6} \mathrm{CH}_{2} \mathrm{OH}$ & 19 & $89 \pm 0.11$ \\
\hline 7 & $\mathrm{CH}_{3}$ & $\mathrm{CH}_{3}\left(\mathrm{CH}_{2}\right)_{5} \mathrm{CHOHCH}_{3}$ & 18 & $92 \pm 0.08$ \\
\hline 8 & $\mathrm{Ph}$ & $\mathrm{CH}_{3}\left(\mathrm{CH}_{2}\right)_{5} \mathrm{CHOHCH}_{3}$ & 24 & $89 \pm 0.11$ \\
\hline
\end{tabular}

${ }^{a}$ Reaction conditions: carboxylic acid (5 mmol), alcohol (2 mmol), and catalyst $(0.03 \mathrm{~g})$. ${ }^{\mathrm{b}}$ /solated yields.

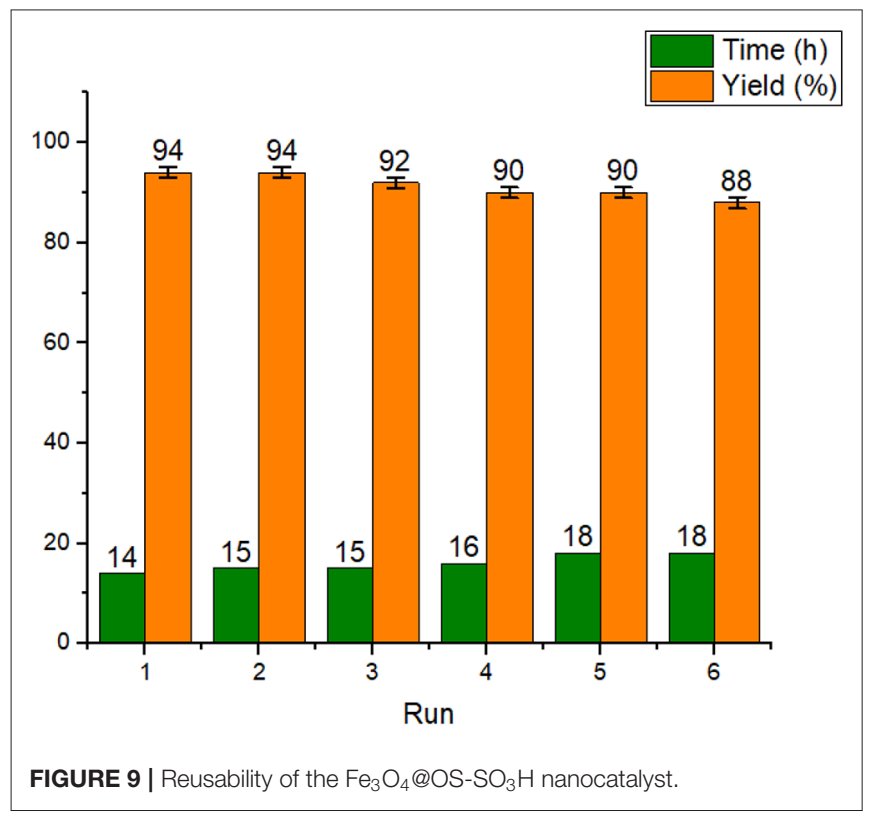

The PXRD of the recovered $\mathrm{Fe}_{3} \mathrm{O}_{4} @ \mathrm{OS}-\mathrm{SO}_{3} \mathrm{H}$ also showed six peaks at $2 \theta=30.18,35.68,43.30,54.12,57.37$, and 62.91 degrees, which are in good agreement with the PXRD pattern of the fresh nanocatalyst. This analysis confirms the high stability of the crystalline structure of $\mathrm{Fe}_{3} \mathrm{O}_{4}$ nanoparticles during several reuse stages. It also important to mention that the appearance of a broad peak at $2 \theta=20-25$ degrees, corresponding to the organosilica layer, proves that the organosilica shell remains after several times of recycling and reuse (Figure 11).

Next, a hot filtration test was performed to investigate the nature of the catalyst under the applied conditions. For this, after completion of about $50 \%$ of the esterification process, the

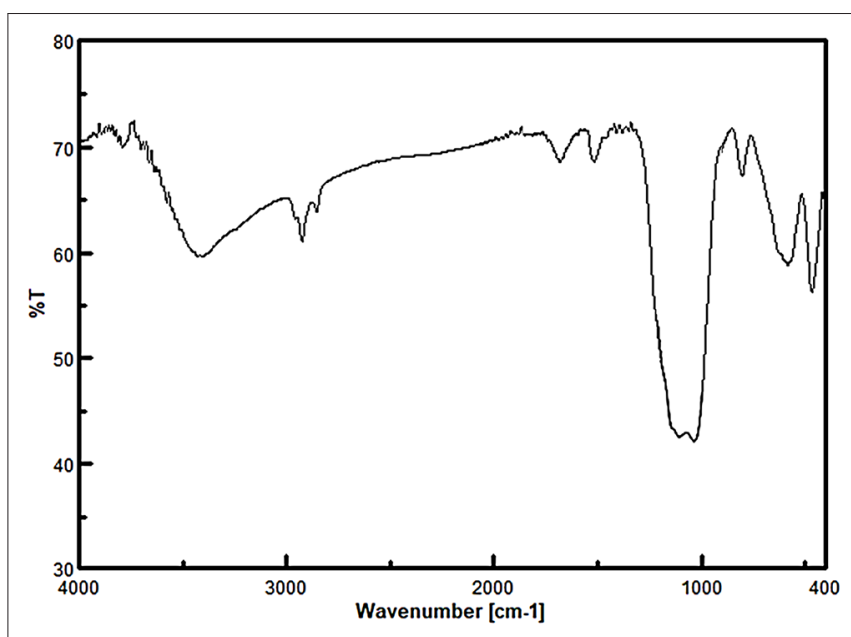

FIGURE 10 | FT-IR spectrum of the recovered $\mathrm{Fe}_{3} \mathrm{O}_{4} @ \mathrm{OS}-\mathrm{SO}_{3} \mathrm{H}$ nanocatalyst.

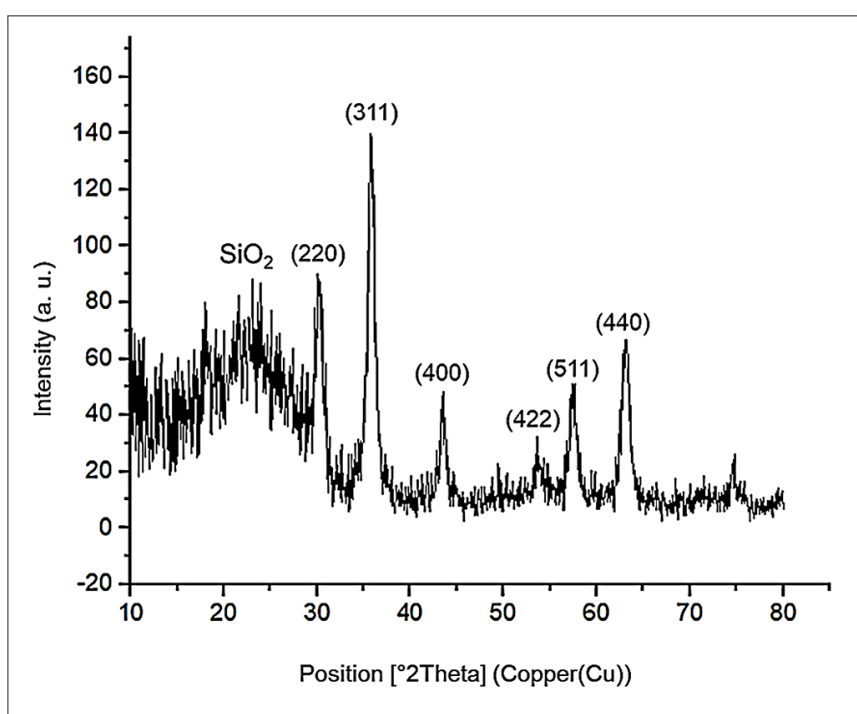

FIGURE 11 | PXRD pattern of the recovered $\mathrm{Fe}_{3} \mathrm{O}_{4} @ \mathrm{OS}-\mathrm{SO}_{3} \mathrm{H}$ nanocatalyst.

TABLE 3 | The comparison study between the efficiency of the present catalyst with that of other catalysts ${ }^{a}$.

\begin{tabular}{lllll}
\hline Entry Catalyst & Conditions & $\begin{array}{c}\text { Recovery Reference } \\
\text { times }\end{array}$ \\
\hline 1 & $\mathrm{GO}$ & Cat. $50 \mathrm{wt} \%, 100^{\circ} \mathrm{C}, 24 \mathrm{~h}$ & 5 & $\begin{array}{l}\text { Chen et al., } \\
2017\end{array}$ \\
2 & $\mathrm{~S}-\mathrm{MlL}-101$ & Cat. $0.05 \mathrm{~g}, 70^{\circ} \mathrm{C}, 7 \mathrm{~h}$ & 3 & Hu et al., 2020 \\
3 & $\mathrm{GO}$ & Cat. $0.1 \mathrm{~g}, 120^{\circ} \mathrm{C}, 6 \mathrm{~h}$ & 4 & Gao et al., 2015 \\
4 & $\mathrm{SO}_{4} / \mathrm{Mg}-\mathrm{Al}-\mathrm{Fe}_{3} \mathrm{O}_{4}$ & Cat. $4 \mathrm{wt} \%, 95^{\circ} \mathrm{C}, 5 \mathrm{~h}$ & 5 & $\begin{array}{l}\text { Gardy et al., } \\
2019\end{array}$ \\
5 & $\mathrm{Fe}_{3} \mathrm{O}_{4} @ \mathrm{OS}-\mathrm{SO}_{3} \mathrm{H}$ & Cat. $0.03 \mathrm{~g}, 70^{\circ} \mathrm{C}, 14 \mathrm{~h}$ & 6 & This work \\
\hline
\end{tabular}

${ }^{a}$ GO, graphene oxide; MIL, Material Institute Lavoisier.

catalyst was removed using a magnetic field and the progress of the residue mixture was monitored. Interestingly, no further conversion was observed in this case. This result confirms no 
leaching and the high stability of supported sulfonic acid moieties under reaction conditions.

Finally, the catalytic performance of the $\mathrm{Fe}_{3} \mathrm{O}_{4} @ \mathrm{OS}-\mathrm{SO}_{3} \mathrm{H}$ nanocatalyst was compared with that of a number of previously reported catalysts in the esterification process (Table 3). As demonstrated, the efficiency of the present catalyst is much higher than that of most of previously reported systems in terms of recycling times, reaction time, and reaction temperature. These findings may be attributed to the magnetic properties and good lipophilicity of the present catalyst.

\section{CONCLUSION}

In summary, in the present study, for the first time a novel sulfonic acid containing magnetic methylene-based organosilica with a core-shell structure $\left(\mathrm{Fe}_{3} \mathrm{O}_{4} @ \mathrm{OS}-\mathrm{SO}_{3} \mathrm{H}\right)$ was prepared as an effective nanocatalyst for biodiesel production. The SEM and TEM images of $\mathrm{Fe}_{3} \mathrm{O}_{4} @ \mathrm{OS}-\mathrm{SO}_{3} \mathrm{H}$ demonstrated spherical particles with a core-shell structure for this material. The FTIR analysis confirmed the successful immobilization of sulfonic acid groups on the $\mathrm{Fe}_{3} \mathrm{O}_{4} @ O S$ nanostructure. The VSM analysis proved the good magnetic properties of $\mathrm{Fe}_{3} \mathrm{O}_{4} @ \mathrm{OS}-\mathrm{SO}_{3} \mathrm{H}$, and PXRD analysis confirmed the high stability of $\mathrm{Fe}_{3} \mathrm{O}_{4} \mathrm{NPs}$

\section{REFERENCES}

Abaeezadeh, S., Elhamifar, D., Norouzi, M., and Shaker, M. (2019). Magnetic nanoporous MCM-41 supported ionic liquid/palladium complex: an efficient nanocatalyst with high recoverability. Appl. Organomet. Chem. 33:e4862. doi: 10.1002 aoc.4862

Adam, F., Batagarawa, M., Hello, K., and Al-Juaid, S. (2012). One-step synthesis of solid sulfonic acid catalyst and its application in the acetalization of glycerol: crystal structure of cis-5-hydroxy-2-phenyl-1, 3-dioxane trimer. Chem. Pap. 66, 1048-1058. doi: 10.2478/s11696-012-0203-x

Adeniyi, A. G., Ighalo, J. O., Adeoye, A. S., and Onifade, D. V. (2019). Modelling and optimisation of biodiesel production from Euphorbia lathyris using ASPEN Hysys. Appl. Sci. 1:1452. doi: 10.1007/s42452-019-1522-0

Aissou, K., Alnasser, T., Pecastaings, G., Goglio, G., Toulemonde, O., Mornet, S., et al. (2013). Hierarchical assembly of magnetic L1 0-ordered FePt nanoparticles in block copolymer thin films. J. Mater. Chem. C 1, 1317-1321. doi: 10.1039/C2TC00490A

Antonello, A., Jakob, G., Dolcet, P., Momper, R., Kokkinopoulou, M., Landfester, K., et al. (2017). Synergy of miniemulsion and solvothermal conditions for the low-temperature crystallization of magnetic nanostructured transitionmetal ferrites. Chem. Mater. 29, 985-997. doi: 10.1021/acs.chemmater. 6b03467

Bohara, R. A., Thorat, N. D., and Pawar, S. H. (2016). Role of functionalization: strategies to explore potential nano-bio applications of magnetic nanoparticles. RSC Adv. 6, 43989-44012. doi: 10.1039/C6RA02129H

Chen, H., Deng, C., and Zhang, X. (2010). Synthesis of $\mathrm{Fe}_{3} \mathrm{O}_{4} @ \mathrm{SiO}_{2} @$ PMMA core-shell-shell magnetic microspheres for highly efficient enrichment of peptides and proteins for MALDI-ToF MS analysis. Angew. Chem. Int. Edn. 49, 607-611. doi: 10.1002/anie.200904885

Chen, X.-R., Ju, Y.-H., and Mou, C.-Y. (2007). Direct synthesis of mesoporous sulfated silica-zirconia catalysts with high catalytic activity for biodiesel via esterification. J. Phys. Chem. C 111, 18731-18737. doi: 10.1021/jp0749221

Chen, Z., Wen, Y., Fu, Y., Chen, H., Ye, M., and Luo, G. (2017). Graphene oxide: an efficient acid catalyst for the construction of esters from acids and alcohols. Synlett 28, 981-985. doi: 10.1055/s-0036-1588399

Chiang, Y. D., Dutta, S., Chen, C. T., Huang, Y. T., Lin, K. S., Wu, J. C., et al. (2015). Functionalized $\mathrm{Fe}_{3} \mathrm{O}_{4} @$ silica core-shell nanoparticles as microalgae during the modification process. TG analysis proved the good immobilization of sulfonic acid and methylene functional groups onto/into the material framework and showed the high thermal stability of the Fe3O4@OS-SO3H nanocatalyst. The $\mathrm{Fe}_{3} \mathrm{O}_{4} @ \mathrm{OS}$ $\mathrm{SO}_{3} \mathrm{H}$ nanocatalyst was effectively applied in the esterification of carboxylic acids as an effective process for biodiesel synthesis. Also, this catalyst could be recycled and reused several times with its activity kept.

\section{DATA AVAILABILITY STATEMENT}

All datasets generated for this study are included in the article/supplementary material.

\section{AUTHOR CONTRIBUTIONS}

All authors listed have made a substantial, direct and intellectual contribution to the work, and approved it for publication.

\section{ACKNOWLEDGMENTS}

The authors thank Yasouj University and the Iran National Science Foundation (INSF) for supporting this work. harvester and catalyst for biodiesel production. ChemSusChem 8, 789-794. doi: $10.1002 /$ cssc. 201402996

Colombo, M., Carregal-Romero, S., Casula, M. F., Gutiérrez, L., Morales, M. P., Böhm, I. B., et al. (2012). Biological applications of magnetic nanoparticles. Chem. Soc. Rev. 41, 4306-4334. doi: 10.1039/c2cs15337h

Dai, Q., Berman, D., Virwani, K., Frommer, J., Jubert, P.-O., Lam, M., et al. (2010). Self-assembled ferrimagnet- polymer composites for magnetic recording media. Nano Lett. 10, 3216-3221. doi: 10.1021/nl1022749

Demirer, G. S., Okur, A. C., and Kizilel, S. (2015). Synthesis and design of biologically inspired biocompatible iron oxide nanoparticles for biomedical applications. J. Mater. Chem. B 3, 7831-7849. doi: 10.1039/C5TB00931F

Dimian, A. C., and Rothenberg, G. (2016). An effective modular process for biodiesel manufacturing using heterogeneous catalysis. Catal. Sci. Technol. 6, 6097-6108. doi: 10.1039/C6CY00426A

Dos Santos-Durndell, V. C., Peruzzolo, T. M., Ucoski, G. M., Ramos, L. P., and Nakagaki, S. (2018). Magnetically recyclable nanocatalysts based on magnetite: an environmentally friendly and recyclable catalyst for esterification reactions. Biofuel Res. J. 5, 806-812. doi: 10.18331/BRJ2018.5.2.4

Elhamifar, D., Karimi, B., Moradi, A., and Rastegar, J. (2014). Synthesis of sulfonic acid containing ionic-liquid-based periodic mesoporous organosilica and study of its catalytic performance in the esterification of carboxylic acids. ChemPlusChem 79, 1147-1152. doi: 10.1002/cplu.201402071

Elhamifar, D., Ramazani, Z., Norouzi, M., and Mirbagheri, R. (2018). Magnetic iron oxide/phenylsulfonic acid: a novel, efficient and recoverable nanocatalyst for green synthesis of tetrahydrobenzo [b] pyrans under ultrasonic conditions. J. Colloid Interface Sci. 511, 392-401. doi: 10.1016/j.jcis.2017.10.013

Esfahani, F. K., Zareyee, D., and Yousefi, R. (2014). Sulfonated core-shell magnetic nanoparticle $\left(\mathrm{Fe}_{3} \mathrm{O}_{4} @ \mathrm{SiO}_{2} @ \mathrm{PrSO}_{3} \mathrm{H}\right)$ as a highly active and durable protonic acid catalyst; synthesis of coumarin derivatives through Pechmann reaction. ChemCatChem 6, 3333-3337. doi: 10.1002/cctc.201402547

Gandhi, A. C., Pradeep, R., Yeh, Y.-C., Li, T.-Y., Wang, C.-Y., Hayakawa, Y., et al. (2018). Understanding the magnetic memory effect in Fe-doped NiO nanoparticles for the development of spintronic devices. ACS Appl. Nano Mater. 2, 278-290. doi: 10.1021/acsanm.8b01898

Gao, X., Zhu, S., and Li, Y. (2015). Graphene oxide as a facile solid acid catalyst for the production of bioadditives from glycerol esterification. Catal. Commun. 62, 48-51. doi: 10.1016/j.catcom.2015.01.007 
Gardy, J., Nourafkan, E., Osatiashtiani, A., Lee, A. F., Wilson, K., Hassanpour, A., et al. (2019). A core-shell $\mathrm{SO}_{4} / \mathrm{Mg}-\mathrm{Al}-\mathrm{Fe}_{3} \mathrm{O}_{4}$ catalyst for biodiesel production. Appl. Catal. B Environ. 259:118093. doi: 10.1016/j.apcatb.2019.118093

Ghorbani-Vaghei, R., and Izadkhah, V. (2018). Preparation and characterization of hexamethylenetetramine-functionalized magnetic nanoparticles and their application as novel catalyst for the synthesis of pyranopyrazole derivatives. Appl. Organomet. Chem. 32:e4025. doi: 10.1002/aoc.4025

Haas, M. J., Adawi, N., Berry, W. W., Feldman, E., Kasprzyk, S., Ratigan, B., et al. (2010). Butter as a feedstock for biodiesel production. J. Agric. Food Chem. 58, 7680-7684. doi: $10.1021 /$ jf1003754

Häfeli, U. O., Riffle, J. S., Harris-Shekhawat, L., Carmichael-Baranauskas, A., Mark, F., Dailey, J. P., et al. (2009). Cell uptake and in vitro toxicity of magnetic nanoparticles suitable for drug delivery. Mol. Pharmaceutics 6, 1417-1428. doi: $10.1021 / \mathrm{mp} 900083 \mathrm{~m}$

Hajian, R., and Ehsanikhah, A. (2018). Manganese porphyrin immobilized on magnetic MCM-41 nanoparticles as an efficient and reusable catalyst for alkene oxidations with sodium periodate. Chem. Phys. Lett. 691, 146-154. doi: 10.1016/j.cplett.2017.11.009

Hamoudi, S., and Kaliaguine, S. (2003). Sulfonic acid-functionalized periodic mesoporous organosilica. Microporous Mesoporous Mater. 59, 195-204. doi: 10.1016/S1387-1811(03)00311-1

Hu, S., Guan, Y., Wang, Y., and Han, H. (2011). Nano-magnetic catalyst $\mathrm{KF} / \mathrm{CaO}-\mathrm{Fe}_{3} \mathrm{O}_{4}$ for biodiesel production. Appl. Energy 88, 2685-2690. doi: 10.1016/j.apenergy.2011.02.012

Hu, S., Luo, X., Wan, C., and Li, Y. (2012). Characterization of crude glycerol from biodiesel plants. J. Agric. Food Chem. 60, 5915-5921. doi: 10.1021/jf3008629

Hu, X., Ma, K., Sabbaghi, A., Chen, X., Chatterjee, A., and Lam, F. L. (2020). Mild acid functionalization of metal-organic framework and its catalytic effect on esterification of acetic acid with n-butanol. Mol. Catal. 482:110635. doi: 10.1016/j.mcat.2019.110635

Iglesias, D., Sabater, S., Azua, A., and Mata, J. A. (2015). Catalytic applications of magnetic nanoparticles functionalized using iridium N-heterocyclic carbene complexes. New J. Chem. 39, 6437-6444. doi: 10.1039/C5NJ00803D

Kainz, Q. M., and Reiser, O. (2014). Polymer-and dendrimer-coated magnetic nanoparticles as versatile supports for catalysts, scavengers, and reagents. Acc. Chem. Res. 47, 667-677. doi: 10.1021/ar400236y

Kalhor, M., and Zarnegar, Z. (2019). Fe3O4/SO3Hlite-Y as a novel multi-functional and magnetic nanocatalyst for clean and soft synthesis of imidazole and perimidine derivatives. RSC Adv . 9, 19333-19346. doi: 10.1039/C9RA02910A

Kandasamy, G., Sudame, A., Luthra, T., Saini, K., and Maity, D. (2018). Functionalized hydrophilic superparamagnetic iron oxide nanoparticles for magnetic fluid hyperthermia application in liver cancer treatment. ACS Omega 3, 3991-4005. doi: 10.1021/acsomega.8b00207

Kolhatkar, A. G., Chen, Y.-T., Chinwangso, P., Nekrashevich, I., Dannangoda, G. C., Singh, A., et al. (2017). Magnetic sensing potential of $\mathrm{Fe}_{3} \mathrm{O}_{4}$ nanocubes exceeds that of $\mathrm{Fe}_{3} \mathrm{O}_{4}$ nanospheres. ACS Omega 2, 8010-8019. doi: 10.1021/acsomega.7b01312

Kondamudi, N., Strull, J., Misra, M., and Mohapatra, S. K. (2009). A green process for producing biodiesel from feather meal. J. Agric. Food Chem. 57, 6163-6166. doi: $10.1021 /$ jf900140e

Kudr, J., Haddad, Y., Richtera, L., Heger, Z., Cernak, M., Adam, V., et al. (2017). Magnetic nanoparticles: from design and synthesis to real world applications. Nanomaterials 7:243. doi: 10.3390/nano7090243

Lam, Y.-P., Wang, X., Tan, F., Ng, W.-H., Tse, Y.-L. S., and Yeung, Y.-Y. (2019). Amide/iminium zwitterionic catalysts for (Trans) esterification: application in biodiesel synthesis. ACS Catal. 9, 8083-8092. doi: 10.1021/acscatal.9b01959

Lartigue, L., Innocenti, C., Kalaivani, T., Awwad, A., Sanchez Duque, M. D. M., Guari, Y., et al. (2011). Water-dispersible sugar-coated iron oxide nanoparticles. An evaluation of their relaxometric and magnetic hyperthermia properties. J. Am. Chem. Soc. 133, 10459-10472. doi: 10.1021/ja111448t

Laskar, I. B., Rajkumari, K., Gupta, R., Chatterjee, S., Paul, B., and Rokhum, L. (2018). Waste snail shell derived heterogeneous catalyst for biodiesel production by the transesterification of soybean oil. RSC Adv. 8, 20131-20142. doi: $10.1039 / C 8 R A 02397 B$

Lee, J., Lee, Y., Youn, J. K., Na, H. B., Yu, T., Kim, H., et al. (2008). Simple synthesis of functionalized superparamagnetic magnetite/silica core/shell nanoparticles and their application as magnetically separable high-performance biocatalysts. Small 4, 143-152. doi: 10.1002/smll.200700456
Li, J., Wei, Y., Li, W., Deng, Y., and Zhao, D. (2012). Magnetic spherical cores partly coated with periodic mesoporous organosilica single crystals. Nanoscale 4, 1647-1651. doi: 10.1039/c2nr11941b

Lien, Y.-S., Hsieh, L.-S., and Wu, J. C. (2010). Biodiesel synthesis by simultaneous esterification and transesterification using oleophilic acid catalyst. Ind. Eng. Chem. Res. 49, 2118-2121. doi: 10.1021/ie901496h

Liu, C. L., Peng, Y. K., Chou, S. W., Tseng, W. H., Tseng, Y. J., Chen, H. C., et al. (2014). One-step, room-temperature synthesis of glutathione-capped iron-oxide nanoparticles and their application in in vivo T1-weighted magnetic resonance imaging. Small 10, 3962-3969. doi: 10.1002/smll.201303868

Liu, G., Wang, D., Zhou, F., and Liu, W. (2015). Electrostatic self-assembly of Au nanoparticles onto thermosensitive magnetic core-shell microgels for thermally tunable and magnetically recyclable catalysis. Small 11, 2807-2816. doi: $10.1002 / \mathrm{smll} .201403305$

Liu, J.-F., Zhao, Z.-S., and Jiang, G.-B. (2008). Coating $\mathrm{Fe}_{3} \mathrm{O}_{4}$ magnetic nanoparticles with humic acid for high efficient removal of heavy metals in water. Environ. Sci. Technol. 42, 6949-6954. doi: 10.1021/es800924c

Maleki, A., Aghaei, M., Hafizi-Atabak, H. R., and Ferdowsi, M. (2017). Ultrasonic treatment of $\mathrm{CoFe}_{2} \mathrm{O}_{4} @ \mathrm{~B}_{2} \mathrm{O}_{3}-\mathrm{SiO}_{2}$ as a new hybrid magnetic composite nanostructure and catalytic application in the synthesis of dihydroquinazolinones. Ultrason. Sonochem. 37, 260-266. doi: 10.1016/j.ultsonch.2017.01.022

Mejías, R., HernáNdez Flores, P., Talelli, M., Tajada-Herrálz, J. L., Brollo, M. E., Portilla, Y., et al. (2018). Cell-promoted nanoparticle aggregation decreases nanoparticle-induced hyperthermia under an alternating magnetic field independently of nanoparticle coating, core size, and subcellular localization. ACS Appl. Mater. Interfaces 11, 340-355. doi: 10.1021/acsami. $8 \mathrm{~b} 18451$

Meng, X., Seton, H. C., Lu, L. T., Prior, I. A., Thanh, N. T., and Song, B. (2011). Magnetic CoPt nanoparticles as MRI contrast agent for transplanted neural stem cells detection. Nanoscale 3, 977-984. doi: 10.1039/c0nr00846j

Mirbagheri, R., and Elhamifar, D. (2019). Magnetic ethyl-based organosilica supported schiff-base/indium: a very efficient and highly durable nanocatalyst. J. Alloys Compd. 790, 783-791. doi: 10.1016/j.jallcom.2019.03.203

Mondal, J., Sen, T., and Bhaumik, A. (2012). $\mathrm{Fe}_{3} \mathrm{O}_{4} @$ mesoporous SBA-15: a robust and magnetically recoverable catalyst for one-pot synthesis of 3, 4dihydropyrimidin-2 (1 H)-ones via the biginelli reaction. Dalton Trans. 41, 6173-6181. doi: $10.1039 / \mathrm{c} 2 \mathrm{dt} 30106 \mathrm{~g}$

Neysi, M., Zarnegaryan, A., and Elhamifar, D. (2019). Core-shell structured magnetic silica supported propylamine/molybdate complexes: an efficient and magnetically recoverable nanocatalyst. N. J. Chem. 43, 12283-12291. doi: $10.1039 /$ C9NJ01160A

Ni, D., Bu, W., Ehlerding, E. B., Cai, W., and Shi, J. (2017). Engineering of inorganic nanoparticles as magnetic resonance imaging contrast agents. Chem. Soc. Rev. 46, 7438-7468. doi: 10.1039/C7CS00316A

Nikoorazm, M., and Erfani, Z. (2019). Core-shell nanostructure ( $\mathrm{Fe}_{3} \mathrm{O}_{4} @ \mathrm{MCM}$ 41@ Cu-P2C) as a highly efficient and recoverable nanocatalyst for the synthesis of polyhydroquinoline, 5-substituted $1 \mathrm{H}$-tetrazoles and sulfides. Chem. Phys. Lett. 737:136784. doi: 10.1016/j.cplett.2019.136784

Obeid, M. M., Jappor, H. R., Al-Marzoki, K., Al-Hydary, I. A., Edrees, S. J., and Shukur, M. M. (2019). Unraveling the effect of Gd doping on the structural, optical, and magnetic properties of $\mathrm{ZnO}$ based diluted magnetic semiconductor nanorods. RSC Adv. 9, 33207-33221. doi: 10.1039/C9RA04750F

Pan, H., Li, H., Zhang, H., Wang, A., Jin, D., and Yang, S. (2018). Effective production of biodiesel from non-edible oil using facile synthesis of imidazolium salts-based brønsted-lewis solid acid and co-solvent. Energy Convers. Manag. 166, 534-544. doi: 10.1016/j.enconman.2018.04.061

Pourjavadi, A., Hosseini, S. H., Doulabi, M., Fakoorpoor, S. M., and Seidi, F. (2012). Multi-layer functionalized poly (ionic liquid) coated magnetic nanoparticles: highly recoverable and magnetically separable brønsted acid catalyst. ACS Catal. 2, 1259-1266. doi: 10.1021/cs300140j

Qiao, R., Yang, C., and Gao, M. (2009). Superparamagnetic iron oxide nanoparticles: from preparations to in vivo MRI applications. J. Mater. Chem. 19, 6274-6293. doi: 10.1039/b902394a

Ramazani, Z., Elhamifar, D., Norouzi, M., and Mirbagheri, R. (2019). Magnetic mesoporous MCM-41 supported boric acid: a novel, efficient and ecofriendly nanocomposite. Compos. B. Eng. 164, 10-17. doi: 10.1016/j.compositesb.2018.11.063 
Sarno, M., and Iuliano, M. (2019). Highly active and stable $\mathrm{Fe}_{3} \mathrm{O}_{4} /$ Au nanoparticles supporting lipase catalyst for biodiesel production from waste tomato. Appl. Surf. Sci. 474, 135-146. doi: 10.1016/j.apsusc.2018.04.060

Seinberg, L., Yamamoto, S., Gallage, R., Tsujimoto, M., Kobayashi, Y., Isoda, S., et al. (2012). Low temperature solventless synthesis and characterization of $\mathrm{Ni}$ and $\mathrm{Fe}$ magnetic nanoparticles. Chem. Commun. 48, 8237-8239. doi: $10.1039 / \mathrm{c} 2 \mathrm{cc} 33830 \mathrm{k}$

Socha, A. M., and Sello, J. K. (2010). Efficient conversion of triacylglycerols and fatty acids to biodiesel in a microwave reactor using metal triflate catalysts. Org. Biomol. Chem. 8, 4753-4756. doi: 10.1039/c0ob00014k

Tai, Z., Isaacs, M. A., Parlett, C. M., Lee, A. F., and Wilson, K. (2017). High activity magnetic core-mesoporous shell sulfonic acid silica nanoparticles for carboxylic acid esterification. Catal. Commun. 92, 56-60. doi: 10.1016/j.catcom.2017.01.004

Touqeer, T., Mumtaz, M. W., Mukhtar, H., Irfan, A., Akram, S., Shabbir, A., et al. (2019). $\mathrm{Fe}_{3} \mathrm{O}_{4}$-PDA-Lipase as surface functionalized nano biocatalyst for the production of biodiesel using waste cooking oil as feedstock: characterization and process optimization. Energies 13, 1-19. doi: 10.3390/en13010177

Upare, P. P., Yoon, J.-W., Kim, M. Y., Kang, H.-Y., Hwang, D. W., Hwang, Y. K., et al. (2013). Chemical conversion of biomass-derived hexose sugars to levulinic acid over sulfonic acid-functionalized graphene oxide catalysts. Green Chem. 15, 2935-2943. doi: 10.1039/c3gc40353j

Vahidian, M., Elhamifar, D., and Shaker, M. (2020). Core-shell structured magnetic mesoporous silica-titania: a novel, powerful and recoverable nanocatalyst. Polyhedron 178:114326. doi: 10.1016/j.poly.2019.114326

Wang, D., Salmon, L., Ruiz, J., and Astruc, D. (2013). A recyclable ruthenium (II) complex supported on magnetic nanoparticles: a regioselective catalyst for alkyne-azide cycloaddition. Chem. Commun. 49, 6956-6958. doi: $10.1039 /$ c3cc43048k

Wang, J., Zhou, H., Zhuang, J., and Liu, Q. (2015). Magnetic $\gamma-\mathrm{Fe}_{2} \mathrm{O}_{3}$, $\mathrm{Fe}_{3} \mathrm{O}_{4}$, and $\mathrm{Fe}$ nanoparticles confined within ordered mesoporous carbons as efficient microwave absorbers. Phys. Chem. Chem. Phys. 17, 3802-3812. doi: 10.1039/C4CP04228J

Wang, Y., Peng, X., Shi, J., Tang, X., Jiang, J., and Liu, W. (2012). Highly selective fluorescent chemosensor for $\mathrm{Zn}^{2+}$ derived from inorganic-organic hybrid magnetic core/shell $\mathrm{Fe}_{3} \mathrm{O}_{4} @ \mathrm{SiO}_{2}$ nanoparticles. Nanoscale Res. Lett. 7:86. doi: 10.1186/1556-276X-7-86

Wu, W., Jiang, C. Z., and Roy, V. A. (2016). Designed synthesis and surface engineering strategies of magnetic iron oxide nanoparticles for biomedical applications. Nanoscale 8, 19421-19474. doi: 10.1039/C6NR07542H

Xie, W., Han, Y., and Wang, H. (2018). Magnetic $\mathrm{Fe}_{3} \mathrm{O}_{4} / \mathrm{MCM}-41$ compositesupported sodium silicate as heterogeneous catalysts for biodiesel production. Renew. Energy 125, 675-681. doi: 10.1016/j.renene.2018. 03.010

Xie, W., and Huang, M. (2019). Enzymatic production of biodiesel using immobilized lipase on core-shell structured $\mathrm{Fe}_{3} \mathrm{O}_{4} @ \mathrm{MIL}-100(\mathrm{Fe})$ composites. Catalysts 9:850. doi: 10.3390/catal9100850

Yang, F.-X., Su, Y.-Q., Li, X.-H., Zhang, Q., and Sun, R.-C. (2008). Studies on the preparation of biodiesel from zanthoxylum bungeanum maxim seed oil. J. Agric. Food Chem. 56, 7891-7896. doi: 10.1021/jf801364f

Zhang, C., Wang, H., Liu, F., Wang, L., and He, H. (2013). Magnetic core-shell $\mathrm{Fe}_{3} \mathrm{O}_{4} @ \mathrm{C}-\mathrm{SO}_{3} \mathrm{H}$ nanoparticle catalyst for hydrolysis of cellulose. Cellulose 20, 127-134. doi: 10.1007/s10570-012-9839-5

Zhang, H., Li, H., Xu, C. C., and Yang, S. (2019). Heterogeneously chemo/enzyme-functionalized porous polymeric catalysts of highperformance for efficient biodiesel production. ACS Catal. 9, 10990-11029. doi: 10.1021/acscatal.9b02748

Zhang, J., Shin, M. C., David, A. E., Zhou, J., Lee, K., He, H., et al. (2013). Long-circulating heparin-functionalized magnetic nanoparticles for potential application as a protein drug delivery platform. Mol. Pharmaceutics 10, 3892-3902. doi: 10.1021/mp400360q

Zhang, Q., Li, H., and Yang, S. (2018a). Facile and low-cost synthesis of mesoporous $\mathrm{Ti}-\mathrm{Mo} \mathrm{Bi}$-metal oxide catalysts for biodiesel production from esterification of free fatty acids in jatropha curcas crude oil. J. Oleo Sci. 67, 579-588. doi: 10.5650/jos.ess17231

Zhang, Q., Wei, F., Ma, P., Zhang, Y., Wei, F., and Chen, H. (2018b). Mesoporous Al-Mo oxides as an effective and stable catalyst for the synthesis of biodiesel from the esterification of free-fatty acids in non-edible oils. Waste Biomass Valorization 9, 911-918. doi: 10.1007/s12649-017-9865-5

Zhang, Y., Ma, W., Li, D., Yu, M., Guo, J., and Wang, C. (2014). Benzoboroxolefunctionalized magnetic core/shell microspheres for highly specific enrichment of glycoproteins under physiological conditions. Small 10, 1379-1386. doi: $10.1002 / \mathrm{smll} .201302841$

Conflict of Interest: The authors declare that the research was conducted in the absence of any commercial or financial relationships that could be construed as a potential conflict of interest.

Copyright (c) 2020 Shaker and Elhamifar. This is an open-access article distributed under the terms of the Creative Commons Attribution License (CC BY). The use, distribution or reproduction in other forums is permitted, provided the original author(s) and the copyright owner(s) are credited and that the original publication in this journal is cited, in accordance with accepted academic practice. No use, distribution or reproduction is permitted which does not comply with these terms. 